\title{
ОЦЕНКА ИЗМЕНЕНИЯ ГИДРОМОРФОЛОГИЧЕСКИХ, ГИДРОЛОГИЧЕСКИХ И ГИДРОХИМИЧЕСКИХ ПОКАЗАТЕЛЕЙ РЕКИ ЗАПАДНЫЙ БУГ И МЕРОПРИЯТИЯ ПО СНИЖЕНИЮ ИХ НЕГАТИВНЫХ ПОСЛЕДСТВИЙ
}

\author{
В. Н. Корнеев ${ }^{1}$, Е. Е. Петлицкий ${ }^{2}$, К. С. Титов ${ }^{3}$, И. А. Булак ${ }^{4}$ \\ ${ }^{1}$ Начальник отдела мониторинга и государственного водного кадастра \\ Республиканского унитарного предприятия «Центральный научно-исследовательский институт комплексного \\ использования водных ресурсов» (РУП «ЦНИИКИВР»), Минск, Беларусь, e-mail: v_korn@rambler.ru \\ ${ }^{2}$ Старший научный сотрудник отдела мониторинга и государственного водного кадастра \\ РУП «ЦНИИКИВР», Минск, Беларусь, e-mail: evgenij.petlickij@gmail.com \\ ${ }^{3}$ Старший научный сотрудник отдела мониторинга и государственного водного кадастра \\ РУП «ЦНИИКИВР», Минск, Беларусь, e-mail: ktsitou@gmail.com \\ ${ }^{4}$ Старший научный сотрудник отдела мониторинга и государственного водного кадастра \\ РУП «ЦНИИКИВР», Минск, Беларусь, e-mail: i_bulak@tut.by
}

\section{Реферат}

Рассмотрена методология и выполнена оценка гидроморфологических, гидрологических и гидрохимических показателей реки Западный Буг. Приведены результаты изучения источников загрязнения реки Западный Буг, оценки качества воды, русловых процессов и математического моделирования его гидрологического режима с построением карт опасностей и риска наводнений. Предложены мероприятия по снижению негативных последствий изменения гидроморфологических, гидрологических и гидрохимических показателей реки Западный Буг.

Ключевые слова: методика, математическая модель, математическое моделирование, трансграничный перенос загрязнений, гидрологический режим, уровенный режим, скоростной режим, поверхностные воды, скорость течения воды, участок реки, расход воды, поверхностный сток, подземный сток, гидрохимический баланс, морфометрическая информация, Государственный водный кадастр (ГВК), локальный мониторинг (ЛМ), донные отложения, почвогрунты.

\section{ASSESSMENT OF CHANGES IN HYDROMORPHOLOGICAL, HYDROLOGICAL AND HYDROCHEMICAL INDICATORS OF THE WESTERN BUG RIVER AND MEASURES TO REDUCE THEIR NEGATIVE EFFECTS}

\section{Abstract}

\section{N. Korneev, E. E. Petlickij, K. S. Tsitou, I. A. Bulak}

The methodology is considered and the assessment of hydromorological, hydrological and hydrochemical indicators of the river Western Bug iis carried out. The results of the study of sources of pollution of the river Western Bug, assessment of water quality, channel processes and mathematical modeling of its hydrological regime with developing of flood hazard maps and flood risk maps are presented. Measures are proposed to reduce the negative consequences of changes in the hydromorological, hydrological and hydrochemical indicators of the river Western Bug.

Key words: methodology, mathematical model, mathematical modeling, transboundary pollution transfer, hydrological regime, water level regime, water velocity regime, surface waters, water flow rate, river section, water discharge, surface runoff, groundwater flow, hydrochemical balance, morphometric information, State Water Cadaster (SWC), local monitoring (LM), bottom sediments, soil.

\section{Введение}

Представленные в настоящей публикации результаты получены в ходе выполнения задания 2.1.6 «Выполнить оценку изменения гидроморфологических, гидрологических и гидрохимических показателей реки Западный Буг и разработать мероприятия по снижению их негативных последствий» подпрограммы II ГНТП «Природопользование и экологические риски», 2016-2020 гг.

Учитывая, что на реке Западный Буг, посередине которой проходит значительная часть государственной границы Беларуси c Польшей, имеются абразионные участки как с белорусской, так и с польской стороны, определение характеристик изменения гидроморфологических показателей, связанных с изменением береговой линии, являются актуальной задачей. Причем большие изменения береговой линии происходят со стороны правого (белорусского) берега из-за характера течения реки в основном с юга на север и направления вектора силы Кориолиса. Сила Кориолиса, как правило, мала по сравнению с другими силами (в сотни раз меньше силы тяжести, которая, например, обуславливает движение воды в водотоках), однако эффрект ее воздействия становится заметными для движений, происходящих на больших расстояниях и при длительных периодах времени.

К числу актуальных экологических проблем реки Западный Буг относятся проблемы изменения гидрохимических показателей качества воды из-за поступления загрязняющих веществ от точечных и рассредоточенных (диффузных) источников загрязнений. Поэтому вторым компонентом выполнения работ по заданию являлось уточнение характеристик источников загрязнения реки Западный Буг, в том числе проведение комплексных исследований основного источника загрязнений реки Западный Буг со стороны правого берега - биологических прудов и сбросного канала очистных сооружений г. Бреста. Данные оценки основаны на результатах выполненных расчетов трансграничного переноса загрязняющих веществ по реке Западный Буг по основным проблемным показателям и расчетов фильтрации и содержания в потоке фильтрационных вод загрязняющих веществ от биологических прудов очистных сооружений города Бреста.

Река Западный Буг относится к водным объектам с высоким риском наводнений вследствие весенних половодий и дождевых паводков, в результате которых могут происходить значительные затопления прибрежных территорий, включая пограничную инфраструктуру, сельскохозяйственные угодья и объекты, жилые и иные строения. Поэтому третьим компонентом работ по заданию являлась оценка изменения гидрологических показателей - оценка гидрологического режима реки Западный Буг при опасных гидрометеорологических явлениях, приводящих к наводнениям. Такая оценка выполнена с использованием математического моделирования водного 
Вестник Брестского государственного технического университета. 2021

режима реки Западный Буг. Математическое моделирование включало подготовку координат поперечных сечений реки Западный Буг с использованием цифровой модели рельефа местности (ЦМР) и результатов измерения глубин воды в характерных створах реки, гидрологические расчеты для различных сценариев максимальной водности и гидравлические расчеты с определением уровней воды и скоростного режима реки. В итоге основным результатом оценки изменения гидрологических показателей являются карты рисков наводнений для трансграничного участка реки Западный Буг на территории Беларуси. Эти карты включают информацию о границах зон затопления, глубинах затопления, а также объекты и виды землепользования, подверженные риску наводнения (затопления) для различных гидрологических сценариев (максимальных расходов в реке Западный Буг заданных вероятностей превышения/ обеспеченностей).

Таблица 1 - Общая характеристика методики проведения оценки гидроморфологических показателей с учетом специфики решаемых задач для реки Западный Буг

\begin{tabular}{|c|c|c|c|}
\hline № п.п. & $\begin{array}{l}\text { Категория, } \\
\text { для каких оценок } \\
\text { используется }\end{array}$ & $\begin{array}{c}\text { Гидроморфологические } \\
\text { показатели }\end{array}$ & Ключевые параметры и методы их определения \\
\hline 1 & $\begin{array}{l}\text { Геометрия русла - } \\
\text { для общей оценки } \\
\text { меандрирования реки }\end{array}$ & $\begin{array}{l}\text { Извилистость реки, } \\
\text { ветвление русла }\end{array}$ & $\begin{array}{l}\text { Коэффициент извилистости реки } k_{\text {изв }} \text { определяется известным способом: } \\
\text { как отношение длины реки (рассматриваемого участка) к кратчайшему } \\
\text { расстоянию между истоком и устьем (между границами рассматриваемого } \\
\text { участка) с использованием современного картографического материала } \\
\text { и ГИС }\end{array}$ \\
\hline 2 & $\begin{array}{l}\text { Донные отложения - } \\
\text { для оценки устойчивости } \\
\text { русла и вертикальных } \\
\text { (глубинных) десрормаций } \\
\text { русла }\end{array}$ & $\begin{array}{l}\text { Общая характеристика } \\
\text { донных отложений }\end{array}$ & $\begin{array}{l}\text { Средний диаметр частиц грунта } d \text {, мм определяется по результатам } \\
\text { отбора проб донных отложений и анализа его гранулометрического } \\
\text { (механического) состава }\end{array}$ \\
\hline 3 & $\begin{array}{l}\text { Характер эрозии, } \\
\text { отложений - для выявления } \\
\text { особенностей русла } \\
\text { и основания берега }\end{array}$ & $\begin{array}{l}\text { Наличие отмелей и островов } \\
\text { (поросших растительность } \\
\text { или непокрытых) }\end{array}$ & $\begin{array}{l}\text { Географические координаты и размещение в плане отмелей } \\
\text { и островов определяются в ходе маршрутных (экспедиционных) } \\
\text { исследований или с использованием современного картографичческого } \\
\text { материала, данных ДЗ3 }\end{array}$ \\
\hline 4 & $\begin{array}{l}\text { Характеристики } \\
\text { течения воды - } \\
\text { для оценки } \\
\text { гидрологического режима } \\
\text { и устойчивости русла } \\
\end{array}$ & $\begin{array}{l}\text { Характеристики скоростного } \\
\text { режима течений для живого } \\
\text { сечения реки }\end{array}$ & $\begin{array}{l}\text { Средняя скорость течения в живом сечении (измеренная или расчетная), } \\
\text { при необходимости - распределение в нем местных продольных скоростей. } \\
\text { Средние скорости на вертикалях в живом сечении реки определяются } \\
\text { по результатам прямых гидрометрических измерений на скоростных } \\
\text { вертикалях в живом сечении реки, либо расчетным методом }\end{array}$ \\
\hline 5 & Устойчивость русла & $\begin{array}{l}\text { Характеристики допускаемых } \\
\text { (неразмывающих) скоростей }\end{array}$ & $\begin{array}{l}\text { Оценка устойчивости русла выполняется путем сравнения средних } \\
\text { на вертикалях скоростей течения в живом сечении с допускаемыми } \\
\text { (неразмывающими) скоростями течения }\end{array}$ \\
\hline 6 & $\begin{array}{l}\text { Наличие } \\
\text { гидротехнических } \\
\text { и других сооружений, } \\
\text { влияющих } \\
\text { на гидрологический } \\
\text { режим реки } \\
\end{array}$ & $\begin{array}{l}\text { Общее описание сооружений: } \\
\text { плотины; дамбы; шлюзы; } \\
\text { примыкающие к реке водоот- } \\
\text { водящие или водоподводя- } \\
\text { щие трубы; трубопроводы, } \\
\text { пересекающие реку } \\
\end{array}$ & $\begin{array}{l}\text { Географические координаты и размещение в плане гидротехнических } \\
\text { и других сооружений, при необходимости - измеренные координаты } \\
\text { поперечного сечения реки с учетом указанных объектов - определяются } \\
\text { в ходе маршрутных (экспедиционных) исследований или с использованием } \\
\text { современного картографического материала, данных ДЗ3 }\end{array}$ \\
\hline 7 & $\begin{array}{l}\text { Берега реки/ прибрежные } \\
\text { зоны - для оценки } \\
\text { плановых и вертикальных } \\
\text { дефрормаций берега }\end{array}$ & $\begin{array}{l}\text { Актуальные географические } \\
\text { координаты левого и правого } \\
\text { берега, а также середины } \\
\text { реки } \\
\text { Отметки высот левого } \\
\text { и правого берега, а также } \\
\text { островов и отмелей } \\
\text { Характеристика грунтов } \\
\text { (породы), слагающей берег: } \\
\text { песок, глина, гравий, } \\
\text { искусственные материалы; } \\
\text { растительность } \\
\text { и ее характеристика } \\
\end{array}$ & $\begin{array}{l}\text { Плановые (горизонтальные) деформаций, } b_{2}, \text { м определяется путем } \\
\text { сравнения актуальных координат берега, например по данным ДЗ3 } \\
\text { с историческими данными топографических карт по возможности наиболее } \\
\text { крупного масштаба (1:25 000 и менее). Оценка значимости этих изменений } \\
\text { путем сравнения величин смещения берегов с использованием критерия } \\
\text { значимости планового смещения, превосходящего в год } 5 \% \text { от его ширины. } \\
\text { Предварительно осуществляется совмещение снимков Д33 с исторической } \\
\text { картографической информацией по возможности наиболее крупного } \\
\text { масштаба (1:25 000 и менее). } \\
\text { Величина прогнозных вертикальных (глубинных) деформаций берега } \\
\text { определяется по специальным зависимостям с учетом характеристик } \\
\text { грунтов (породы), слагающей берег и его защиту (при ее наличии) }\end{array}$ \\
\hline 8 & $\begin{array}{l}\text { Пойма реки - } \\
\text { для уточнения оценки } \\
\text { плановых деформаций } \\
\text { берега }\end{array}$ & $\begin{array}{l}\text { Общая характеристика } \\
\text { расположенных на пойме } \\
\text { природных и антропогенных } \\
\text { объектов, которые могут } \\
\text { влиять на деформации } \\
\text { берега реки }\end{array}$ & $\begin{array}{l}\text { Географические координаты и размещение в плане расположенных } \\
\text { на пойме природных и антропогенных объектов, которые могут влиять } \\
\text { на деформации берега реки, при необходимости - измеренные координаты } \\
\text { поперечного сечения реки с учетом указанных объектов, включая защитные } \\
\text { дамбы, польдеры, каналы, рыбоводческие садки, гравийные и другие } \\
\text { карьеры, пойменный лес, сельскохозяйственные, городские земли, } \\
\text { водно-болотные угодья }\end{array}$ \\
\hline
\end{tabular}

По результатам выполнения научно-исследовательских работ по перечисленным выше трем компонентам разработана Программа мероприятий по снижению негативных последствий изменений гидроморфологических, гидрологических и гидрохимических показателей реки Западный Буг и снижению риска наводнений.

Общая характеристика результатов оценки изменения гидроморфологических, гидрологических и гидрохимических показателей реки Западный Буг

Гидроморфологические показатели. Для оценки изменения гидроморфологических показателей разработана методика и программа проведения оценки гидроморфологических показателей. Общая характеристика указанной методики приведена в таблице 1. 
С использованием приведенной методики путем проведения экспедиционных исследований и последующих расчетов выполнена оценка изменения гидроморфологических показателей реки Западный Буг. Основными факторами, которые привели к смещению линии середины реки Западный Буг, выступили: абразия (размыв) берегов, прорыв меандров, многорукавность (образование отмелей и островов). Максимальное определенное смещение составило 470 м. Выявлено 36 участков реки Западный Буг со значительным (более 100 м) смещением линии середины реки за 35-летний период. В том числе выявлено 198 участков многорукавности (образования отмелей и островов) и 93 участка абразии правого берега При этом величина абразии правого берега на трансграничном участке реки Западный Буг за 35-летний период (1981-2016 годы) на 255 участках составила 3,665 км² $^{2}(366,5$ га). Естественные гидроморфологические изменения реки Западный Буг привели как абразии правого берега (смещения русла вправо), так и к аккумуляции правого берега (смещения русла влево). Величина аккумуляции правого берега на трансграничном участке протекания реки Западный Буг за 35-летний период (1981-2016 гг.) на 252 участках составила 4,137 км² (413,7 га). Несмотря на то, что общий баланс абразии и аккумуляции правого берега реки Западный Буг за 35-летний период (1981-2016 гг.) положительный для Беларуси на всем трансграничном участке протекания реки Западный Буг (+47,2 га), следует отметить интенсивную превалирующую абразию правого берега на «верхнем участке» реки Западный Буг от государственной границы «Беларусь-Украина» до н.п. Домачево, а также ряд отдельных участков с интенсивной абразией правого берега (более 3 га) на «среднем участке» от н. п. Домачево до г. Бреста и «нижнем участке» от г. Брест до н. п. Крынки.

На основании выполненного анализа выявленных 93 проблемных участков реки Западный Буг и территорий, которые могут быть под риском переформирования правого берега и изменения месторасположения середины реки, выделено 8 участков с наиболее значимыми изменениями правого берега (рисунок 1), три из которых являются наиболее проблемными. Это участки у ДСТ «Рубеж» в районе пункта пропуска «Козловичи» и 1,5 км выше впадения реки Лесной (выше и ниже «петли», огибающей полуостров). Для этих трех участков разработана программа мероприятий по снижению негативных последствий изменения гидроморфологических показателей, основу которой составляет мониторинг состояния правого берега и его укрепление на данных участках.

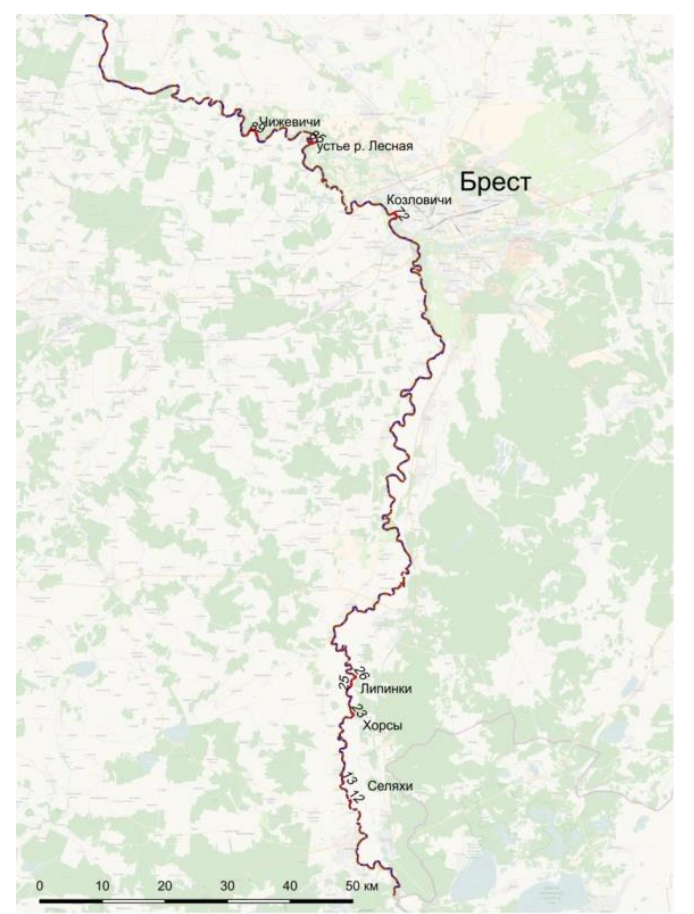

Рисунок 1 - Схема наиболее проблемных участков реки Западный Буг по степени изменения гидроморфорфологических показателей
Гидрохимические показатели. При оценке изменения гидрохимических показателей по данным статистической отчетности по форме «1-вода (Минприроды)» выявлено 62 водопользователя, оказывающих прямое или опосредованное воздействие на реку Западный Буг и ее притоки 1-го порядка. При этом 18 водопользователей сбрасывают сточные воды в поверхностные водные объекты. Всего выявлено 4 выпуска в реку Западный Буг. 33 водопользователя осуществляют сброс сточных вод после очистки на 39 очистных сооружениях естественной биологической очистки - полях филььтрации, которые оказывают опосредованное воздействие на рядом расположенные поверхностные водные объекты, в том числе 3 - на реку Западный Буг. В границах водоохранных зон и прибрежных полос, а также в зоне инженерных сооружений Государственной границы Республики Беларусь расположено 40 объектов, оказывающие негативное воздействие на реку Западный Буг и ее притоки 1-го порядка. В том числе 10 объектов расположено вдоль реки Западный Буг, наиболее значимый из них - биологические пруды очистных coopyжений города Бреста.

Наиболее значимый источник загрязнения реки Западный Буг сброс сточных вод с очистных сооружений города Бреста. На очистных сооружениях г. Бреста эксплуатируются четырехступенчатые биологические пруды (левый и правый каскады) в количестве 8 штук, работающие в режиме естественной аэрации.

Значения показателей очищенных сточных вод очистных coopyжений города Бреста перед их сбросом в биопруды в основном не превышали установленных допустимых концентраций (ДК). Исключение составляли концентрации взвешенных веществ и азота общего. Не представляет угрозы для реки Западный Буг и загрязнение от сбросов в составе очищенных сточных вод ОС города Бреста металлов и нефтепродуктов в связи с незначительными концентрациями относительно уровня их фонового содержания в воде реки. Однако следует отметить, что на этапе доочистки сточных вод в биопрудах качество этих сточных вод вдоль их следования до реки Западный Буг ухудшалось по основным приоритетным загрязняющим веществ (фосфрору общему и азоту общему), что свидетельствовало о вторичном загрязнении очищенных сточных вод. Воздействие очищенных сточных вод очистных сооружений города Бреста на реку Западный Буг являлось значимым по биогенным загрязняющим веществам - азоту и фосфору, в меньшей степени - по биохимическому потреблению кислорода (БПК5) и химическому потреблению кислорода (ХПК сг). Фактическое значение по БПК5 и ХПК сr превышали установленные значения показателей качества для поверхностных водных объектов в фоновом створе выше сброса, что свидетельствует о загрязнении реки по этим показателям выше по течению.

Изучение характеристик илонакопителей и биологических прудов КПУП «Брестводоканал» по фондовым данным статотчетности водопользователей и локального мониторинга, а также их экспедиционные обследования позволили сделать вывод о том, что основным дополнительным источником вторичного загрязнения реки Западный Буг являлись биологические пруды, в которые сбрасывались очищенные сточные воды очистных сооружений города Бреста. Вместе с тем илонакопители не являются значимыми источниками загрязнения реки Западный Буг, они имеют защитный экран и напрямую не связаны с рекой Западный Буг какими-либо водоводами или водотоками. К тому же основные илонакопители уже либо ликвидированы, либо находятся в стадии ликвидации (проведена либо проводится их рекультивация). Выполненные расчеты фильтрации в районе биопрудов и содержания в них загрязняющих веществ с использованием данных локального мониторинга подземных вод в наблюдательных скважинах, расположенных ниже дамб биопрудов вблизи реки Западный Буг и локального мониторинга сточных вод, проводимых КПУП «Брестводоканал», результатов экспедиционных исследований и проектной документации показали, что несмотря на то, что биопруды оборудованы защитным противофилльтрационным экраном, на их территории вероятно существуют слабопроницаемые фильтрационные окна, через которые происходит фильтрация сточных вод и геомиграция в них загрязняющих 
Вестник Брестского государственного технического университета. 2021

веществ. Для предотвращения вторичного загрязнения очищенных сточных вод по результатам проведенных НИО обоснованы мероприятия по необходимости сброса очищенных сточных вод в реку Западный Буг по сбросному коллектору, минуя загрязненные за предыдущие годы биологические пруды. КПУП «Брестводоканал» выполнено строительство данного коллектора.

Другие инженерные мероприятия по снижению негативных последствий изменения гидрохимических показателей реализовываются в рамках реализации Плана управления бассейном реки Западный Буг, утвержденного 10.12.2019 совместным решением № 735/739 Брестского и Гродненского областных исполнительных комитетов.

Гидрологические показатели. Оценка изменения гидрологических показателей для различных сценариев неблагоприятных гидрометеорологических явлений, связанных с наводнениями, выполнена с использованием методов математического моделирования водного режима реки Западный Буг на всем протяжении ее трансграничного участка между Республикой Беларусь и Республикой Польша.

Математическая модель основана на численном решении системы уравнений в частных производных математической физики, описывающей неустановившееся движение воды в системе водотоков - системой одномерных (1D) уравнений Сен-Венана гиперболического типа [1]. В качестве начальных и граничных условий использовалась информация по максимальным наводнениям в бассейне реки Западный Буг, произошедшим в 1979 году (самое катастрофическое наводнение за весь период наблюдений) и в 1999 году (также очень значительное наводнение), а также результаты прямых гидрометрических измерений, выполненных в ходе экспедиционных исследований по заданию. Граничным условиям для нижней границы расчетного участка использовалась зависимость расхода воды от уровня воды $Q(z)$ для нижнего створа у н. п. Новоселки, которая ввиду отсутствия измеренных данных по расходам воды (гидрологический пост является только уровенным) определена путем гидравлических расчетов пропускной способности поперечного створа данного гидрологического поста. В качестве начальных условий используются значения уровней воды и расходов воды во всех расчетных узлах участка на начальный момент времени перед прохождением паводков, которые определяются при расчете неравномерного установившего движения воды [2].

Результаты математического моделирования положены на картографическую основу с разработкой карт опасностей и риска наводнений с использованием наиболее передовых мировых практик. Методология наилучших практик управления рисками наводнений сформулирована в директиве Европейского парламента и Совета от 23 октября 2007 г. 2007/60/EC по оценке и управлению рисками наводнений (далее по тексту - Директиве по наводнениям) [3] Согласно данной директиве разработка мероприятий по снижению негативного воздействия вод для жизни и здоровья людей, окружающей среды, культурного наследия и экономической деятельности основывается на использовании специализированных карт - карт опасностей и карт рисков наводнений.

Карты опасностей наводнений охватывают территории подверженные негативному воздействию вод, и включают следующую базовую информацию:

- вероятную зону затопления;

- глубины воды либо уровни воды;

- скорости течения и расходы воды на исследуемой территории.

Карты рисков наводнений отображают потенциальные неблагоприятные последствия затоплений и содержат следующие сведения:

- ориентировочная численность населения, потенциально затрагиваемая затоплением;

- виды экономической деятельности, потенциально затрагиваемые затоплением;

- сооружения и территории, которые могут привести к загрязнению поверхностных вод при затоплении;

- виды охраняемых территорий, потенциально затрагиваемых затоплением.
Карты опасностей и рисков наводнений разрабатываются для базовых гидрологических сценариев с расчётом соответствующего водного режима. В качестве сценариев используются гидрологические условия, соответствующие весенним половодьям, повторяемостью один раз в сто лет (1 \% вероятности превышения/ВП или обеспеченности), один раз в двадцать лет (5 \% ВП), один раз в десять лет (10 \% ВП).

Для математического моделирования в качестве граничных условий используются соответствующие этим гидрологическим условиям максимальные расходы воды и соответствующие им уровни воды в реке Западный Буг в створах измерений городов Влодава и Кшичев, измеряемые польской стороной, а также уровни воды, измеряемые белорусской стороной на гидрологическом посту у н. п. Новоселки. Поскольку со стороны Беларуси не выполняются измерения расходов воды в реке Западный Буг, для математического моделирования использовались данные, полученные от польской стороны в ходе сотрудничества по международному проекту по обмену опытом стран ЕС в области оценки и управления рисками наводнений FLOOD-WISE [4]. Расчетные расходы воды в реке Западный Буг створах гидрологических постов у г. Влодавы и г. Кшичева, соответствующие заданным неблагоприятным сценариям наводнений, определены с использованием ТКП 45-3.04-168-2009 [5] и П1-98 к СНиП 2.01.14-83 [6]. Идентификация (настройка) математической модели с использованием измеренных уровней и расходов, а также по данным наблюдений польской стороны о максимальных расходах весенних половодий 1979 и 1999 годов выполнялась по локальным вдоль участков периметров поперечных сечений коэффициентам шероховатости и боковой приточности. Пример карты риска наводнений приведен на рисунках 2 и 3.

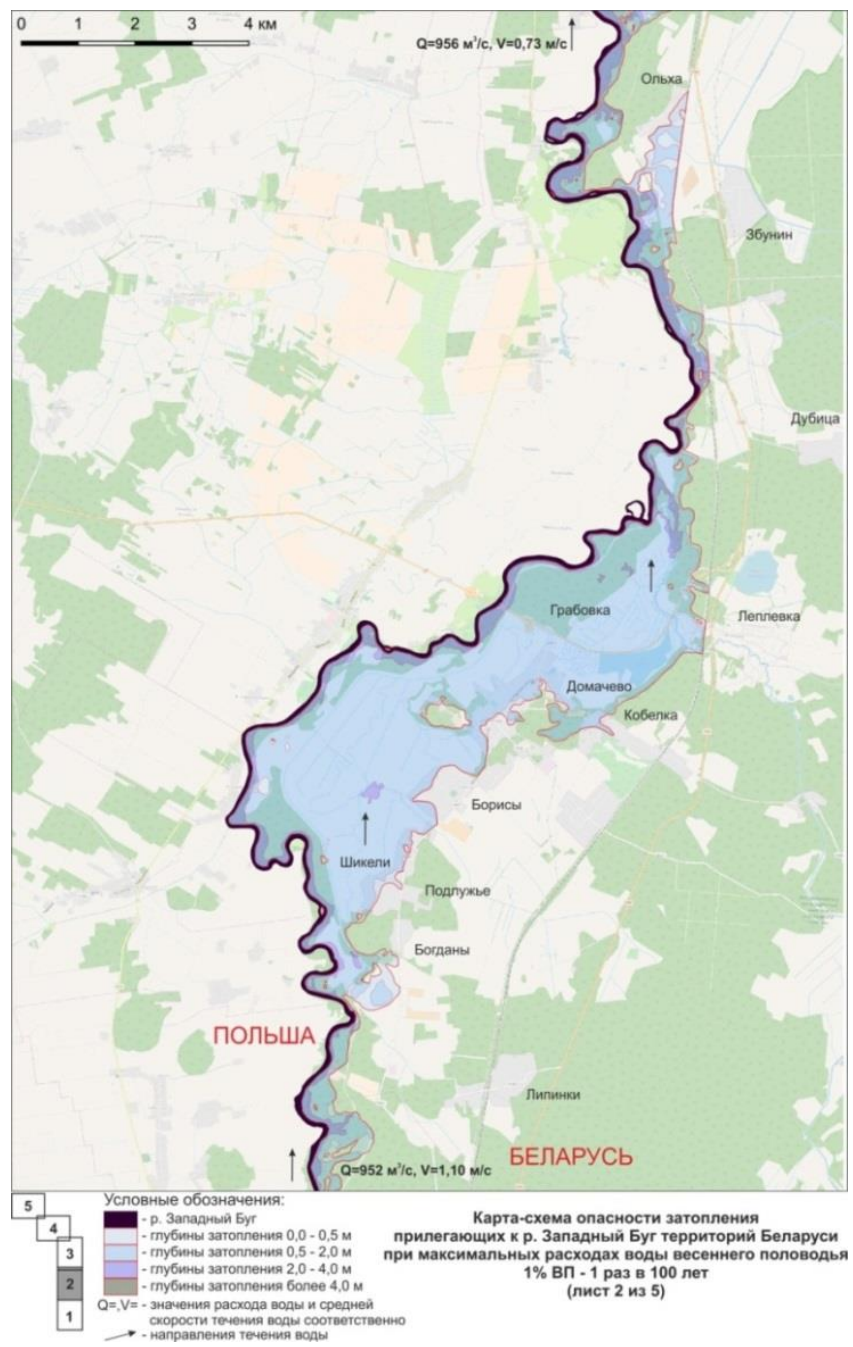

Рисунок 2 - Пример карты-схемы опасности наводнений (затоплений) 
Вестник Брестского государственного технического университета. 2021

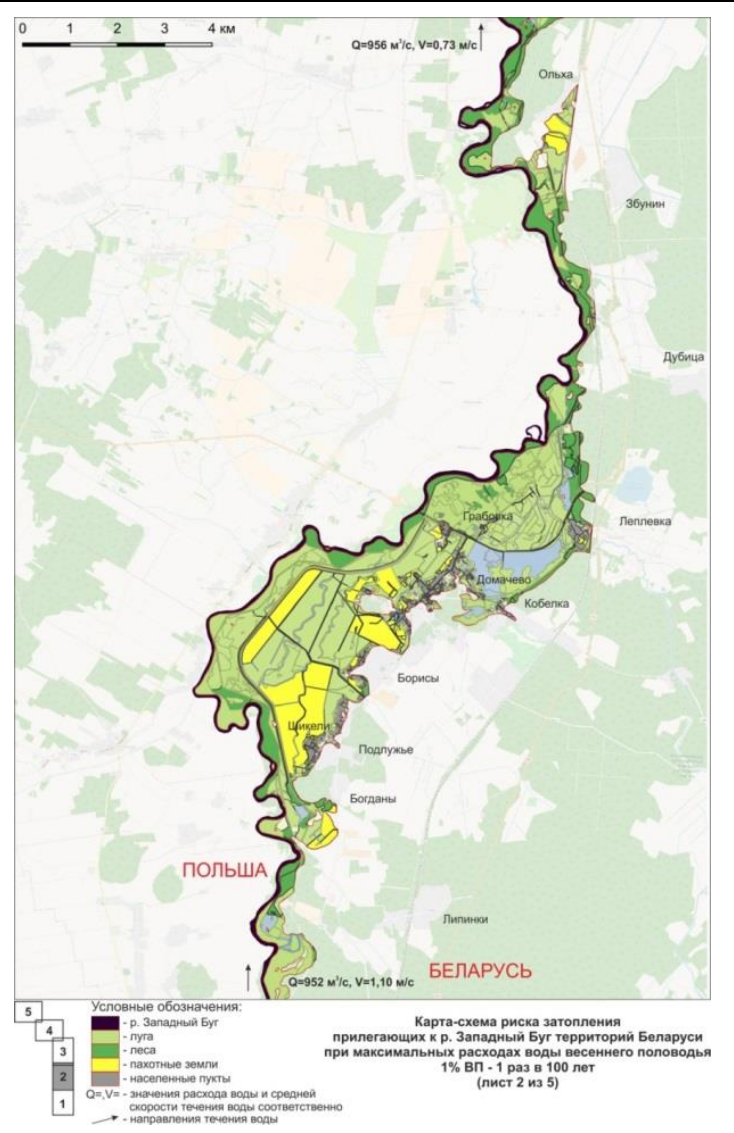

Рисунок 3 - Пример карты-схемы риска наводнений (затоплений)
Характеристики опасности и риска затопления трансграничного участка реки Западный Буг на территории Беларуси в соответствии с гидрологическими сценариями 10 \% ВП, 5 \% ВП, 1 \% ВП приведены в таблицах 2 и 3 соответственно.

Таблица 2 - Характеристики опасности затопления трансграничного участка реки Западный Буг на территории Беларуси

\begin{tabular}{|l|c|c|c|}
\hline \multicolumn{1}{|c|}{ Характеристика } & 10 \% ВП & 5 \% ВП & $1 \%$ ВП \\
\hline Площадь зоны затопления, км² & 139 & 154 & 167 \\
\hline $\begin{array}{l}\text { Максимальная ширина } \\
\text { зоны затопления, км }\end{array}$ & 5,22 & 5,45 & 5,59 \\
\hline $\begin{array}{l}\text { Средняя ширина зоны } \\
\text { затопления, км }\end{array}$ & 0,82 & 0,91 & 0,99 \\
\hline Максимальная глубина, м & 7,28 & 7,76 & 8,11 \\
\hline $\begin{array}{l}\text { Расход воды в входном } \\
\text { створе участка, м3/с }\end{array}$ & 529 & 657 & 947 \\
\hline $\begin{array}{l}\text { Расход воды в выходном } \\
\text { створе участка, м3/с }\end{array}$ & 840 & 1030 & 1420 \\
\hline $\begin{array}{l}\text { Средняя скорость течения } \\
\text { воды на участке, м/с }\end{array}$ & 0,77 & 0,74 & 0,72 \\
\hline $\begin{array}{l}\text { Время течения воды по участку, } \\
\text { часы: минуты: секунды }\end{array}$ & $73: 12: 22$ & $79: 01: 17$ & $85: 31: 23$ \\
\hline
\end{tabular}

Мероприятия по снижению негативных последствий изменений гидрологических показателей реки Западный Буг и снижению риска наводнений основаны на предложениях по своевременному раннему оповещению в случае наводнений и инженерной защите от наводнений наиболее уязвимых территорий и объектов. При этом также учитываются мероприятия подпрограммы 7 «Инженерные противопаводковые мероприятия» Государственной программы развития аграрного бизнеса в Республике Беларусь на 2016-2020 годы.

Таблица 3 - Характеристики риска затопления трансграничного участка реки Западный Буг на территории Беларуси для населения

\begin{tabular}{|c|c|c|c|c|c|c|}
\hline \multirow[b]{2}{*}{ Населенный пункт } & \multicolumn{2}{|c|}{$10 \%$ ВП } & \multicolumn{2}{|c|}{$5 \% \mathrm{~B} \Pi$} & \multicolumn{2}{|c|}{$1 \% \mathrm{~B} \Pi$} \\
\hline & $\begin{array}{c}\text { Кол-во жилых } \\
\text { строений }\end{array}$ & $\begin{array}{c}\text { Ориентировочное } \\
\text { количество жителей }\end{array}$ & $\begin{array}{c}\text { Кол-во жилых } \\
\text { строений } \\
\end{array}$ & $\begin{array}{c}\text { Ориентировочное } \\
\text { количество жителей }\end{array}$ & $\begin{array}{c}\text { Кол-во жилых } \\
\text { строений }\end{array}$ & $\begin{array}{c}\text { Ориентировочное } \\
\text { количество жителей }\end{array}$ \\
\hline Томашевка & 3 & 6 & 8 & 16 & 17 & 34 \\
\hline Комаровка & 30 & 60 & 68 & 136 & 85 & 170 \\
\hline Селяхи & 16 & 32 & 25 & 50 & 33 & 66 \\
\hline Приборово & 99 & 198 & 129 & 258 & 150 & 300 \\
\hline Подлужье & 70 & 140 & 75 & 150 & 81 & 162 \\
\hline Шикели & 15 & 30 & 19 & 38 & 22 & 44 \\
\hline Борисы & 16 & 32 & 18 & 36 & 27 & 54 \\
\hline Домачево & 133 & 266 & 180 & 360 & 224 & 448 \\
\hline Кобелка & - & - & 29 & 58 & 30 & 60 \\
\hline Леплевка & 45 & 90 & 49 & 98 & 70 & 140 \\
\hline Дубица & - & - & 6 & 12 & 6 & 12 \\
\hline Ольха & - & - & - & - & 45 & 90 \\
\hline Заказанка & 80 & 160 & 120 & 240 & 145 & 290 \\
\hline Прилуки & 56 & 112 & 137 & 274 & 180 & 360 \\
\hline Козловичи & 400 & 800 & 650 & 1300 & 750 & 1500 \\
\hline СТ Рубеж & 50 & 100 & 80 & 160 & 100 & 200 \\
\hline Речица (Брест) & 140 & 280 & 190 & 380 & 263 & 526 \\
\hline Брест Западный & 12 & 24 & 12 & 24 & 12 & 24 \\
\hline Волынка & 100 & 200 & 200 & 400 & 250 & 500 \\
\hline Аркадия & 200 & 400 & 200 & 400 & 500 & 1000 \\
\hline Гершоны & 100 & 200 & 120 & 240 & 200 & 400 \\
\hline Митьки & - & - & - & - & 50 & 100 \\
\hline Котельня Боярская & - & - & - & - & 55 & 110 \\
\hline Бернады & - & - & - & - & 10 & 20 \\
\hline Клейники & 205 & 410 & 287 & 574 & 400 & 800 \\
\hline Непли & 60 & 120 & 78 & 156 & 60 & 120 \\
\hline Пески & 37 & 74 & 48 & 96 & 35 & 70 \\
\hline Костычи & 50 & 100 & 50 & 100 & 50 & 100 \\
\hline Шумаки & 13 & 26 & 18 & 36 & 30 & 60 \\
\hline Теребунь & 38 & 76 & 42 & 84 & 50 & 100 \\
\hline Галачево & 10 & 20 & 15 & 30 & 15 & 30 \\
\hline Огородники & 2 & 4 & 2 & 4 & 2 & 4 \\
\hline Итого & 1980 & 3960 & 2855 & 5710 & 3947 & 7894 \\
\hline
\end{tabular}


Вестник Брестского государственного технического университета. 2021

Общая характеристика изменения гидроморфоологических, гидрологических и гидрохимических показателей реки Западный Буг при характеристиках минимального стока с учетом изменения климата. Согласно результатам исследований, представленным в [7], в бассейне реки Западный Буг за счет изменения климата за период с 1961 по 2015 год произошло уменьшение стока во все характерные периоды. В том числе среднегодовой сток уменьшился на 10-20\%, сток в зимний период - на 5-15\%, в весенний период - на 15-30\% и в летний период - на 10-30 \%. Согласно оценкам, приведенным в [7], прогнозируется, что на период до 2035 года в бассейне Западного Буга среднегодовой сток, а также сток в весенний и осенний период будет изменяться незначительно, в зимний период он даже может незначительно (до $10 \%$ ) увеличиться за счет увеличения оттепелей и количества осадков. Однако в летний период прогнозируется дальнейшее уменьшение стока - максимально на 15-25 \%. Одним из отрицательных последствий изменения климата для бассейна реки Западный Буг может являться возможное увеличение частоты и интенсивности неблагоприятных метеорологических и гидрологических явлений, таких как ливни, засухи, наводнения, обусловленные дождевыми паводками и весенними половодьями, особенно при соединении факторов таяния снега и осадков в виде мокрого снега и дождя. Несмотря на общее потепление в бассейне реки Западный Буг, в последние десять лет наблюдались катастрофические наводнения во многих государствах включая Венгрию, Чехию, Германию, Балканские государства, Францию, Великобританию, Испанию, Италию и др.

Не менее важной является оценка изменения гидроморфологических показателей реки (их уязвимость) при минимальном стоке основным из которых является глубина течения воды - максимальная в поперечном сечении при расчетном уровне воды, соответствующем лимитирующим характеристикам стока [8].

С учетом прогнозного уменьшения речного стока Западного Буга при лимитирующих характеристиках стока, близких к экологическому стоку, мелководные участки с максимальными в поперечных сечениях глубинами воды менее 1,5 м будут составлять до $40 \%$ от длины расчетного участка, менее 1,0 м - до $14 \%$ от длины расчетного участка. При лимитирующих характеристиках стока, близких к минимальным наблюденным характеристикам стока (в период очень маловодного 2015 года), мелководные участки с максимальными в поперечных сечениях глубинами воды менее 1,5 м будут составлять до 77 \% от длины расчетного участка, менее $1,0 \mathrm{M}$ - до $49 \%$ от длины расчетного участка.

Изменение климата, в том числе повышение температуры воздуха, может привести к повышению температуры воды в поверхностных водных объектах. В среднем по бассейну реки Западный Буг повышение температуры воды до середины XXI века может составить $1^{\circ} \mathrm{C}$. В результате содержание растворенного кислорода в поверхностных водах в летний период может снизиться на 0,25 мг/дм в среднем по бассейну. Это изменение не является существенным в случае высоких концентраций растворенного кислорода, но может стать значительным при низких его концентрациях. В результате снижения содержания растворенного кислорода может произойти изменение гидрохимических показателей (увеличение концентрации биогенных загрязняющих веществ), а также ухудшение гидробиологических показателей качества поверхностных вод.

\section{Заключение}

Результаты оценки изменения гидроморфологических показателей позволили выделить восемь участков реки Западный Буг с наиболее значимыми изменениями правого берега, три из которых являются наиболее проблемными. Для этих трех участков предложены мероприятий по мониторингу состояния правого берега и его укреплению. Результаты оценки изменения гидрохимических показателей позволили обосновать и в последующем реализовать мероприятия по организации сброса очищенных сточных вод КПУП «Брестводоканал» в реку Западный Буг по сбросному коллектору, минуя загрязненные за предыдущие годы биологические пруды. По результатам оценки изменения гидрологических показателей и математического моделирования водного режима реки Западный Буг разработаны карты опасностей и рисков наводнений для базовых сценариев максимальных расходов воды весеннего половодья, а также предложены мероприятия по инженерной защите от наводнений наиболее уязвимых территорий и объектов.
Разработанные методические подходы и опыт их применения на примере реки Западный Буг при оценке изменения гидроморфологических, гидрологических и гидрохимических показателей может быть использован на других реках Республики Беларусь, что повысит информационное обеспечение по водным объектам и будет способствовать улучшению комплексного управления водными ресурсами.

Реализация мероприятий по снижению негативных последствий изменения гидроморфологических, гидрологических и гидрохимических показателей реки Западный Буг позволит улучшить экологическое состояние реки Западный Буг и повысить экологическую безопасность в бассейне.

\section{Список цитированных источников}

1. Кюнж, Ж. А. Численные методы в задачах речной гидравлики (практическое применение) / Ж. А. Кюнж, Ф. Н. Холли, А. Вервей. М. : Энергоатамиздат, 1985. - с. 256.

2. Станкевич, А. П. Уточнение коэфффициентов шероховатости для системы водотоков бассейна р. Припяти / А. П. Станкевич // Проблемы Полесья. - 1982. - Вып. 8. - С. 149-155.

3. Директива 2007/60/EC Европейского Парламента и Совета от 23 октября 2007 г, по оценке и управлению рисками наводнений [Электронный ресурс]. - Режим доступа: http://eur-lex.europa.eu/legal-content/EN/TXT/?uri=CELEX:32007L0060.

4. Towards cross-border flood risk management. Results of FLOODWISE: cooperation in six European border rivers. - The Interreg IV C, 2012. $-94 \mathrm{C}$.

5. ТКП 45-3.04-168-2009 «Расчетные гидрологические характеристики. Порядок определения».

6. П1-98 к СНиП 2.01.14-83 "Определение расчётных гидрологических характеристик". - Минск : Министерство архитектуры и строительства Республики Беларусь, 2000. - 174 с.

7. Водные ресурсы Беларуси и их прогноз с учетом изменения климата / под общей редакцией А. А. Волчека, В. Н. Корнеева. Брест: Альтернатива, 2017. - 228 с.

8. П-ООС 17.06-03-2017. Пособие в области охраны окружающей среды и природопользования «Охрана окружающей среды и природопользование. Гидросфера. Порядок расчета лимитирующих гидрологических и гидравлических характеристик поверхностных водных объектов». - Минск : 2017. - 6 с.

9. Введ. 01.05.2010. - Минск : Минстройархитектуры, 2014. - 52 с.

\section{References}

1. Kyunzh, ZH. A. CHislennye metody v zadachah rechnoj gidravliki (prakticheskoe primenenie) / ZH. A. Kyunzh, F. N. Holli, A. Vervej. M. : Energoatamizdat, 1985. - s. 256.

2. Stankevich, A. P. Utochnenie koefficientov sherohovatosti dlya sistemy vodotokov bassejna r. Pripyati / A. P. Stankevich // Problemy Poles'ya. - 1982. - Vyp. 8. - S. 149-155.

3. Direktiva 2007/60/ES Evropejskogo Parlamenta i Soveta ot 23 oktyabrya $2007 \mathrm{~g}$, po ocenke i upravleniyu riskami navodnenij [Elektronnyj resurs]. - Rezhim dostupa: http://eur-lex.europa.eu/ᄀlegalcontent/EN/TXT/?uri=CELEX:32007L0060.

4. Towards cross-border flood risk management. Results of FLOODWISE: cooperation in six European border rivers. - The Interreg IV C, 2012. $-94 \mathrm{C}$.

5. TKP 45-3.04-168-2009 «Raschetnye gidrologicheskie harakteristiki. Poryadok opredeleniya».

6. P1-98 k SNiP 2.01.14-83 "Opredelenie raschyotnyh gidrologicheskih harakteristik". - Minsk : Ministerstvo arhitektury i stroitel'stva Respubliki Belarus', 2000. - $174 \mathrm{~s}$.

7. Vodnye resursy Belarusi $i$ in prognoz $s$ uchetom izmeneniya klimata / pod obshchej redakciej A. A. Volcheka, V. N. Korneeva. - Brest: Al'ternativa, 2017. - $228 \mathrm{~s}$.

8. P-OOS 17.06-03-2017. Posobie v oblasti ohrany okruzhayushchej sredy i prirodopol'zovaniya «Ohrana okruzhayushchej sredy i prirodopol'zovanie. Gidrosfera. Poryadok rascheta limitiruyushchih gidrologicheskih i gidravlicheskih harakteristik poverhnostnyh vodnyh ob"ektov». - Minsk : 2017. - 6 c.

9. Vved. 01.05.2010. - Minsk : Minstrojarhitektury, 2014. $-52 \mathrm{~s}$. 